УДК 141.7:004.056.57:316.4

DOI: https://doi.org/10.26661/hst-2019-2-79-07

\title{
BASIC STRATEGIC TECHNOLOGY OF INTELLECTUAL DUALITY OF HUMANITY IN INFORMATION TECHNOLOGY
}

\author{
(C) PUNCHENKO, OLEG
}

Odessa State Academy of Technical Requlation and Quantity (Odessa, Ukraine) E-mail: olegpetr02.09@gmail.com, ORCID iD: https://orcid.org/0000-0003-2694-6841 Odessa State Academy of Technical Requlation and Quantity, 5, Kovalska str., Odesa, 65020, Ukraine

\section{CPUNCHENKO, NATALIA}

Odessa State Academy of Technical Requlation and Quantity (Odessa, Ukraine) E-mail: olegpetr02.09@gmail.com, ORCID iD: https://orcid.org/0000-0003-1382-4490 Odessa State Academy of Technical Requlation and Quantity, 5, Kovalska str., Odesa, 65020, Ukraine

\begin{abstract}
The article includes new conceptual explanation of civilization content as an information process. Civilization is revealed as a global sociocultural "quantum" based on a specific picture for civilization and alien to others. The analysis of civilizational "quanta" historically reveals spiritual synergy of the past humanity with reconstructing goal of its entire positive present. This analysis is a product of our reflection thinking on those fractal objects of civilization as a "quantum" - "invariants" that are extracted from the space of its worldviews and events. According to the exponential growth of information production in all civilizational "quanta", basic strategic technologies in information space are revealed as a result of ever-increasing intellectual activity of mankind in its processing, storage and protection. The basic strategic technologies include: coding, symbolization and digitalization. Coding is disclosed as a dialectical process of the relationship of thought and sign, the translation of thought into a sign; the epistemological nature of the sign and the sign situation is explained. The value-cognitive status of symbolization is analyzed. The symbol is characterized as a form of representing the ideal expression of things, phenomena and processes in image or sign form. Digital technologies, as an integral feature of the third industrial revolution, in unfolding context of its new stage - the fourth, are developing in basic strategiccontext of the entire information space, covering all areas of civilizations from the standpoint of its innovative development.
\end{abstract}

Key words: civilization, "quantum", information, coding, sign, symbolization, semiotics, digitalization, technology.

Formulation of the problem in general form of its connection with important scientific and practical tasks

An analysis of the civilizational mankind history in the unity of its material and spiritual production allows us to axiomatically assert impossible ways to bring development of civilization process under the same scheme; an internal logic of being for each civilization has its own. It is based on a concrete picture of life activity common to a given civilization and alien to the rest. This 
picture reveals civilization as a complex, multi-level system.

In this picture, the process of information production was a common, fundamental principle that integrates the civilizations of the Ancient East, Ancient West and Latin American pre-Columbian civilizations into a single whole, and today it has become the personification of all the leading countries of the world. This allows you to represent civilization as an information process. This process was complicated in connection with the development of the intellectual activity of mankind in the field of information production. The exponential growth of information has forced human intelligence to seek not only new ways of its production, but also technologies for its processing, transmission, storage and protection. The study of these processes allowed us to formulate the purpose of the article, which is to justify the coding, symbolization and digitalization of information as the basic strategic technologies developed by human intelligence in the information space.

Analysis of recent research and publications on the subject

This issue, in connection with the latest research on the essence of information and its role in social development, as well as its exponential growth, the creation of a new type of human resources information, has been reflected in the latest scientific research. In addition to technologies related to the integration, minimization and simplification of information content, its coding, symbolization, digitalization, and information security have become more global. These problems are reflected in the works of P. Vodopyanov. ("The Strategy of the Being of Humanity", Minsk, 2018); Voronkova V.G. ("Information suspension in Ukraine and Ukraine: problems of becoming and development of law", Zaporozhye, 2017); V.Lukashevich ("Creative Interaction of Subject Normative and Reflexive Knowledge", Minsk, 2019); A.Levko ("Sociocultural prerequisites for innovative development", Minsk, 2018); N.Zakharchenko ("Information parameters of positive and timer codes", Odessa, 2018);

I.Karabelskaya ("The use of digital technologies in the educational process of higher education", Ufa, 2017); O.Punchenko ("Archeology of no sphere education", Odessa, 2017); K.Schwab ("Fourth Industrial Revolution", M., 2016); V.Starzhinsky, V.Tsepkalo ("Towards an Innovation Society", Minsk, 2016); A.Lazarevich ("The Formation of the Information Society", Minsk, 2015); O.Punchenko

("Civilizational dimension of the history of mankind", Odessa, 2013) and others. In earlier studies, but already in the $21 \mathrm{st}$ century, the problems of civilizational development of man were widely reflected. These include the work of E. Toffler (The Third Wave, M., 2004); S.Huntington ("The Clash of Civilizations", M., 2005); R.Osbourne ("Civilization", M., 2008);

A.Fernando-Armestro

("Civilizations", M., 2009); D.Naysbita ("Chinese megatrends", M., 2012); L.Mosionzhnika ("Anthropology of Civilizations", 
Chisinau, 2006); V.Molostova ("Aging and death of civilizations", Rostov, 2005) and others.

An analysis of aforementioned works reveals close relationship between the civilizational and informational developments of mankind, which allowed authors to represent civilization as an informational process.

Discussion of the problem. The study of the history of mankind from the standpoint of its civilizational development has firmly entered not only the epicenter of sociophilosophical problems, but also the whole complex of scientific knowledge, which is permeated today by the justification of various aspects of information civilization. Currently, this topic is developing so intensively that it has even turned into the academic discipline of "civilizational science" and is read in many Westernuniversities.

The study of the civilizational development of society provides rich material on the formation and development of independent entities regions, states, cities, are characterized as the uniqueness of cultural and historical events, the specifics of material production, and the way of life. This, on the one hand, and on the other, represents the process of human intelligence movement from its formation to the present and makes it possible to predict its future development.

Deep substantiation of the essence and architectonics of the category "civilization" is impossible without an analysis of the key ideas and concepts developed by science in the past. The peculiarity of these ideas and concepts is the logic of the researcher's thought movement, which appears in the form of a critical constructive analysis. Such criticism reflects not only the form of movement of his thought, but it is the moment of development of knowledge, the moment of increment of new knowledge. The emerging new theories in the removed form include old ideas and concepts, which enriches the historical background of the vision of the problem of interest to us, that is, the civilizational development of mankind.

When we talk about civilization today, we mean not so much its current state as those values that we inherited from past generations. But civilizations of the past are not a kind of receptacle of material and spiritual values, but the totality of the historical artifacts they created, the decoding of the contents of which gives us an idea of the way of life of specific communities of the past.

However, when we analyze the experience of past centuries, we somehow level it. This is because science tends to categorize past events without delving into the spirit of the past. Describing the past, R. Osbourne writes that "the past is a country of discoveries, but it serves as a backdrop on which stories unfold. The need for a plot, for the development of a climax makes us look at the past as something that is complex and contradictory, but it makes sense, which ultimately must be deciphered ... However, in this process the everlasting paradox of history appears. Are we giving order to the past, which in reality had no order? 
Are we not looking into the past in search of confidence in the present?" $[19$, p. 72].

Undoubtedly, modeling the past, we compare the leap that humanity has made in its civilizational development to the present, and try to predict it's difficult to predict future. Since the past exists in the reflective field of the cognizing subject, and historical sources only determine the topology, chronology, and concrete content of the past as history, it would be wrong to reduce the reality of the past to the field of subjective experiences. The past is always involved in the present, but does not have its own autonomous ontological representation. It exists, as it were, in the gap between the spiritual world of the knowing subject and the objective world of the past. And it can be argued that the history of mankind, as a whole unique formation, cannot be understood without knowing its basic values and constantly comparing historical integrity with the key moments of the existence of various models of civilizations.

These models are classified as unitary, stadia, and local-historical. The unitary approach, coming from the French and German representatives, justified civilization in the prism of its cultural development as the ideal of the syncretic progressive development of mankind. Civilization in this approach appears as a public monopolistic structure for specific times and peoples. In the stadia aspect, civilization is such a historical period in the development of mankind, which is characterized by the intensive and diverse development of industry, technology, science, communications, art, the social dynamics of life, as well as the unity of worldviews, common features of behavior and the appearance of a person. Here, areas of research of civilizations based on the European approach and not taking into account the fundamental possibilities and features of another world order that are inherent in the Eastern and Latin American civilizations of the past and present are highlighted. As for the localhistorical approach, it considers civilizations as unique communities or historical entities.

This approach to the concept of civilizational development became decisive in the second half of the twentieth century. They began to speak about civilizations in the plural and came to the conclusion "about the need to justify civilizational ingredients, which specify the substrate and structure of civilization. Without specifying these ingredients, according to F. Fernandez-Armestro, civilization is "a unique concept, the existence of which can be doubted" [21, p. 10]. The basis of this doubt is the lack of evidence that all societies have a single characteristic of social being, except that they are all social structures. In his opinion, "civilization in a person's consciousness means a region, group or period characterized by a striking integrity of lifestyle, thinking and feelings" [21, p. 22]. He considers agriculture to be the main ingredients of civilizations, as well as "urban life, religion and literacy turn out to be past selection" [21, p. 24]. He states what characterized the past, 
but the modern ingredients are little affected, there is no clear fractal in his concept of the future. But this is found in S. Huntington [23], R. Osbourne [19], V. Molostov [13], V.Voronkova [8] and others.

An analysis of the essence of civilizations reveals that point of view that reveals it as a specific historical community of people. But civilization is not reduced to the concept of nationality, nation or ethnic group. Each of these layers has its own "art of living." Analysis of this "art of living" allowed L.Mosionzhnik conclude that it is impossible to examine human history in the prism of a community of people, since the above mentioned communities can enter into civilization. And he comes to the conclusion that "humanity is quantized by civilizations" [17, p. 15]. But the question arises: what is this quantum? And how to understand quantum social mechanics?

If a quantum is an integral indivisible unit of information, then quantifiers should reflect the logical equivalents of the structural organization of a community (civilization), thanks to which it exists, that is, we again return to the selection and justification of the vital components of civilization's architectonics, that is, to quantization, as a specific method research as a macroscopic system, which allows us to highlight the laws of its development and describe the structure of civilization, establish the nature of social ties. In this case, it can be argued that civilization as a "quantum" will be a special sociocultural phenomenon.
At the heart of civilization as sociocultural quantum, - notes L.Mosionzhnik, "lies a subjective, imaginary virtual picture of the world, common to a given civilization and alien to everyone else. While this picture at least relatively allows us to explain the surrounding reality and exist in it - civilization can live. And the collapse of this unified picture for everyone is the moment of breakdown - the loss by people of the main thing that united them" [17, p. 19].

At the same time, civilization appears as an information process. This process develops a general picture of the world of a given civilizational structure. All of them developed information, the decoding of which makes it possible to reveal the movement of the intelligence of mankind as a whole. But this movement has a lot in common. Not being closely interconnected, the civilizations of the Ancient East, the Ancient West and the Latin American continent in the pre-Columbian period developed according to a single algorithm - science, technology, writing, architecture, the formation of a worldview, life, etc., but they all had their own characteristics. Therefore, these "quanta" acted as an information process.

The development of the dynamics of these sociocultural "quanta" civilizations gives a systeminformational idea of the process of human history. Each civilization is unique and valuable, and their analysis shows that this uniqueness and value is semantic, conceptual, if viewed from the standpoint of the "load" of their content. 
The conceptual uniqueness of these "quanta" is that civilization reflects the development of spiritual culture, especially traditions, customs, foundations, and everyday life, which fundamentally distinguishes one civilization from another, and represents their uniqueness. The meaning-forming "burden" of the content of these civilizations is revealed more structurally through the use of system-descriptor and systemcybernetic approaches, which make it possible to more reliably, determine the system of components of information processes.

Thus, civilization is a complex, stable, multi-level, multi-faceted and at the same time unique and valuable system of social life, "capable of longterm autonomous existence, possessing the spatial-temporal framework of its being and acting as an information process proceeding in collective activity" [15, p. 123]. It integrates social activity into a single whole and directs people to interact with the environment, during which the organization of public life increases.

The assertion that civilization is an information process, especially revealed its content in the second half of the twentieth century, when humanity turned to the study of the category of "information".

The modern stage of the doctrine of information dates back to the 40s of the twentieth century, and by the end of this century it became the determining one in the system of scientific knowledge. In this system, after the number of definitions of culture (over 600 according to Prof.
Y.Kharina), the definition of "information", which has more than 400 , came in second place. Analysis of this concept and its significance in the life of society became the basis for F. Fukuyama's statement that by the end of the twentieth and the beginning of the twenty-first century there was an "information revolution" with its own tasks and specifics.

The core of the development of the doctrine of information was the theory of communications and cybernetics. The term "information" means "clarification, presentation." In the scientific literature, a different understanding of the content of this term has developed, which has taken shape in a number of scientific approaches to its study. Among them, the most famous are: anthropocentric, techno centric and no centric. The first approach considers information as a totality of information, messages about an object or event; it permeates the science of information, starting from C. Shannon [24] to the present.

The techno centric approach is characteristic of technical sciences. It is based on the concept of the interaction of data and methods. Data is material objects, but it is by no means information. This is the first component of this information model. The second are the methods of reproduction (registered signals) and data processing. As a result, we have information about the nature and content of the object.

The no centric approach is to reject the definition of information because of its fundamental nature and features. 
Nevertheless, the basis of modern information research is anthropocentric. From a different angle, the concept of information and its essence is found in W. Ross, V. Glushkov, L. Brillouin, V. Broydo, G. Golitsyna, V. Petrova, A. Makarova, L. Matveeva, I. Novika, A. Rakitova, A. Holevo and others.

Clear commitment to the idea of C. Shannon that information is information, a collection of messages - is found in the works of N.Zakharchenko Defining information, he writes that "information is information that is the object of transmission, separation, transformation, storage or direct use. This may be information about the results of measurements, observations, calculations. Thus, information should not be understood as objects and processes themselves, but their essential characteristics, their reflection in the form of numbers, formulas, descriptions, drawings, symbols or other abstract characteristics "[6, p. 13]. In another work, he writes that "information is the internal content of the process of reflection of some material objects in the form of changes in the properties of others" [5, p. 7].

In the theory of information, a number of problems are considered, among which, interest to us in connection with our research, these are, first of all, "general laws of transmission, processing and storage of information. They have the nature of conservation laws and establish a number of important border messages, such as the maximum information transfer rate, the most important signal coding efficiency, and the like, general dependencies, which mean those or other factors that affect the conversion, transmission speed, loss, and storage ability information " $[5, \mathrm{p}$. 13].

And what are the ideas of an anthropocentric approach to elucidating the essence of information? So, C. Shannon argues, "that information can be handled almost like physical quantities like mass and energy" [25, p. 41]. Against such an understanding of the essence of information, N. Wiener, the founder of cybernetics, spoke out. Justifying its essence, he opposed the idea of C. Shannon, arguing the thesis about the neutrality of information above matter and consciousness. He writes that "information is not matter and energy" [2, p. 166]. In another place, he notes that "information is a designation of content received from the outside world in the process of our adaptation to it." Here, information is taken in relation to a person as a creative side of communication that leads from the outside world to a person.

And yet, the scientific feat of $\mathrm{N}$. Wiener is the substantiation of the essence of cybernetics, since cybernetic devices today are the full face of the information civilization that expresses the flight of the intellectual activity of mankind in all spheres of life. Describing this scientific feat, P. Vodopyanov and V. Krisachenko writes: "even the creator of cybernetics, Norbert Wiener, could hardly have foreseen what kind of transformations of society this science will lead to. New machines and their 
systems have unprecedentedly strengthened the analytical capabilities of man, and have made it possible to organize production management in a new way. For the first time in the history of mankind, they made it possible for almost every person from civilized countries to quickly access the cumulative experience of mankind stored in computer data banks. Computerization level of society depends technically on the progress of computers" [1, p. 148]. Could Schwab write today about the Fourth Industrial Revolution, which "opened up new possibilities in the creation of new materials widely used in various industries? These include miniature manufacturing devices, artificial intelligence, learning machines and mobile Internet. These achievements are widely used in various fields, from decoding information recorded in human genes to discoveries in the field of nanotechnology, from the widespread use of renewable resources to applications in quantum computing " $[9$, p. 90$]$.

A new approach to information, the substantiation of its essence is found in M. Zarenin, who claims that at various structural levels of matter, in the interaction of matter and energy, various forms of manifestation of information occur. This allows us to claim information as a universal attribute of matter at all its structural levels. In this regard, he notes that "nature does not know the concept of" information "! We are abstracting the signs, connections and properties of objects, we define information as information, messages, data on objects, facts and circumstances, events and phenomena that can be perceived regardless of the form of presentation and interpreted depending on the depth of knowledge of the object or phenomenon "[12, $p$. 25].

However, M. Zarenin goes deeper in the study of information, expressing in a broader and more generalized form the scientific and philosophical understanding of this category. "Information is the signs, properties, features of objects or their images that are transmitted in time and space, reflecting interactions and communicative objective connections in material and non-material form" [12, p. 25].

Information in this sense differs sharply in the content and methodology of its production and from the information that mankind used in previous civilizations as an information process.

Information acts as an objective, universal phenomenon with qualitative and quantitative characteristics. The objectivity and universality of information processes suggests the presence of specific features for various levels of matter in an inorganic and organic nature, in social processes.

Despite the fact that all civilizations appear in the study of their architectonics as information processes, nevertheless, the doctrine of information in the matrix of modern civilization occupies a special place. On its basis, information processes are unfolding; information resources of the society, information technologies and the corresponding 
infrastructure are being formed. Together they form the information sphere, which is the intellectual and technological basis of society.

It is known that the modern stage of the civilizational development of society is characterized by the rapid development of information, which required its strengthening

Processing, the creation of information technology in order to effectively use information in all areas of public life. From this point of view, information technologies include, on the one hand, an understanding of the transmitted and interpreted information as information, messages, data recorded on certain media. On the other hand, they are based on an understanding of technology as an operational process for receiving and processing this information and turning it into a higher level of abstraction.

The general concept of technology expresses "a combination of methods, techniques, processing methods, changing the properties, condition and shape of objects in the process of their production into products" [12, p. 84]. But the main feature of information technologies is that they are created to produce information of a new quality, capable of providing the necessary information result. "Then," writes M. Zarenin, - information technology should be understood as a set of operations performed on information resources using modern technical means and methods for obtaining a specific information product (service) and solving tasks "[12, p. 84].

Information technology can be divided into two groups: general and strategic. The first group of technologies includes processes of integration, simplification and minimization, and the second strategic group of information technologies includes coding, symbolization and digitalization.

The integration of information is the process of combining, interpenetrating and synthesizing sciences into a single whole with the aim of realizing a direct connection between the content of scientific knowledge and the materialtransforming activity of people at a particular stage of socio-historical development. Integration is an integral component of scientific thinking, which accompanies it the entire history of scientific knowledge. At the first stage in Ancient Greece, an attempt was made by Aristotle to build a unified system of sciences, including at that time all known branches of knowledge. The second stage is the mechanistic one, in which an attempt was made to explain all sciences based on the law of mechanics, but it was an external synthesis of sciences. The third stage reflects the process of identifying internal patterns and relationships as an essential characteristic of the whole. The fourth stage is the second half of the twentieth century, the accumulation of information leads to its qualitative restructuring, new theories arise that integrate a wide range of phenomena together, open up space for the synthesis of old and newly obtained information.

Simplification of information is a specific form, a technique for integrating knowledge. In the 
structure of modern scientific knowledge, three types of simplicity are distinguished, to which work with information is reduced.

Firstly, practical simplicity. It reflects the automatic search (algorithm) of a particular procedure within the framework of the problem being investigated.

Secondly, semantic simplicity, it is characterized by the number of assumptions and sentences on which a certain concept is based, the number of possible values of scientific statements in this context, the number of additional hypotheses, fundamental provisions necessary to substantiate specific information.

Thirdly, syntactic simplicity. It characterizes the form of scientific knowledge, the language in which this or that scientific information is exposed. This simplicity is determined by the variety of signs and logical connections between them used in this conceptual scheme, the harmony in the design of scientific information, and the amount of alphabetic symbolism used for knowledge. This simplicity for the most part obeys a fairly accurate quantitative calculation.

The minimization of scientific information is carried out using various techniques and means, but it must be borne in mind that each scientific theory has its own "threshold" of semiotic simplicity. The height of the "threshold" is determined by the completeness and depth of reflection of the nature of the phenomenon being studied, the information content of the system, and the content of the theory.
Any information generated by humanity is a product, an external expression of a subject informational result, created in material and nonmaterial form and intended for circulation among users. According to its content, it can be divided into general; it is open to all for use, and specific, intended for specialists of state use. The second is decisive, since it is related to the information security of society. "Security," notes A. Levko, - regardless of the numerous forms of its manifestation, expresses certain methods of ensuring the life of individual individuals and society as a whole in accordance with physiological, biological, medical, organizational, technical, economic, social and other indicators that are correlated with the norm, as a kind of criterion measures or equilibrium of their being"'[3, p. 187].

In the scientific literature, information security is defined ambiguously, which confirms the multidimensional search for its semantic "load". But having a generally comprehensive nature, the problem of information security is structured in accordance with the most significant areas of social life, "notes A. Lazarevich. - They are: the economic sphere ...; scientific and technical sphere; defense sphere; financial sector; sphere of public consciousness; management sphere; law enforcement"[11, p. 307].

But the problem of enhancing information security requires a new development of various forms of information protection and, above all, coding, symbolization and digitalization. These are not 
innovations, and even in a sense one can agree with Plotin, who back in the third century claimed that all existing theories were born long ago, all that remains for us is to be their exegetes. True, as an ardent follower of Plato, he argued that everything was discovered by Plato. As the production of information especially important for society developed, so did the methods of its protection.

Coding. As a determinative way of protecting information, it permeates the information processes of its production with a duty cycle of about 4000 years. Ancient Egypt, the Ancient East - India, China, and later Japan, the Ancient West - Greece, Rome, as well as the civilizations of the Latin American continent in the pre-Columbian period - Inca, Maya, Aztecs and others dealt with it. Cryptographers claim that the development of coding throughout the production of information reflected the increasingly complicated and at the same time peculiar dual nature of the movement of the intellect of people involved in coding information.

But in society there is always secret information, the interest of which is constantly growing. Its decoding at first was based only on thinking processes, and today - on technical devices, and primarily on computers. The process of decoding information reflects a special level of intellectual development of the individual, the warehouse of his thinking, abilities, knowledge. Today these "information crackers" are hackers in almost all developed countries. A large set of programs in universities for working with information is that fertile ground for their functioning, especially since their own country does not punish them for mastering the military, financial, economic, political secrets of other countries. And today, these "intellectuals" exist in the form of an extra-legal international caste of hackers.

But there were "information crackers" earlier. An interesting example in this respect is the example of Aristotle, who deciphered cryptographic device - wanderer which used during the war of Sparta and Athens. The author of the wanderer, Lysander, called the wooden roller wanderer in form of the staff, on which a ribbon of parchment or skin was carefully wounded. Information was written in rows along the surface. In this form, the tape contained an incomprehensible sequence of letters. They could be read by wrapping a roller of the same diameter. The key to decoding was the diameter of the roller. It is known that in Ancient Greece there was a special atmosphere of moral relations and it never occurred to anyone to take away the staff (wanderer) on which the person (agent) relied. But it so happened that the wanderer fell into the hands of the ruling bodies of Athens, they turned to Aristotle and after hard work decoded the text, handed it to the rulers of Athens and they were too late, but realized the reasons for their defeat in the battles of 407 and 405 . BC, the result of which was the dictation of the conditions of the world and 
imposition of oligarchic rule by the Lysander.

Coding, as a specific working method with information, can be explicated both from philosophical point of view and technical one. From a philosophical point of view, it appears as an epistemological act of translating thought into a sign in which thinking and language, psychology and semiotics are involved, which are closely interconnected in this process. Here, thinking reveals the movement of thought from the general to the individual. Based on this interaction, a sign situation is formed, which refers to the relationship between the source of information and the object to which the sign refers (since it designates it), between the sign as a carrier of information and the subject to whom the sign is given, whose behavior is regulated by this sign.

In principle, any material phenomenon acts as a sign, but only because it denotes another phenomenon, its side or property, sign. Therefore, the phenomenon that plays the role of a sign has a dual nature: in addition to its usual existence, which is due to its natural being, it also leads another existence, entering a certain information space (relation) to other phenomena.

The process of translating thought into a sign is technically difficult and specific. In this regard, a situation characteristic of information includes such moments as the presence of a source of information, its transmitter and carrier, the presence of a certain code that serves to transfer elements of a transmitted message from one isomorphic system to another, and finally, the presence of a consumer of information that uses it to satisfy personal or public goals. Those signs that directly contain information and transmit it appear with respect to the side using it.

A signal always carries encoded information, it is just a way of transmitting it. And "before transmitting the signal, the subject of knowledge is connected with the process of coding of thought, i.e. translating it into a specific sign. The signal reflects the content of the sign, and this is their commonality, but the signal and the sign cannot be identified ... Their dialectical connection lies in the fact that in the most general sense the concept of a signal includes the concept of a sign and means any material phenomenon that acts as a medium of information" [16, p. 271].

Exploring the role of the signal in the activity of the subject, L. Reznikov notes that a signal is a material phenomenon, "warning about the occurrence of a certain action after it or even serving as a means of orienting a person" [22, p. 96]. The signal is "pressed" into the situation; it seems to "peep" out of it through the prism of the immediate needs of the subject. The sign implies abstracting not only from objective characteristics, but also from directly socially individual goals and motives. The advantage of the sign is that "natural matter" is indifferent, "transparent" for its meaning. A sign has objective meaning only because it expresses a certain ideal image, which has nothing to do with the concept of 
this subject. Nevertheless, the dialectic of cognition is such that images could not have been formed without the use of certain signs in cognition. Without the use of signs for the purpose of communication, a person could not have acquired the cognitive prerequisites necessary for the formation of images of reality. This alone speaks of the epistemological nature of the sign and the need for its use in cognitive reality.

The difference between the signal and the sign lies in the fact that the signal is always unidirectional, but the sign implies a reverse, alternative connection, an adequate reaction of communication partners. In a word, a signal appears in humans as a natural means of communication, and a sign is an artificial tool of communication and cognition.

From a technical point of view, "coding is the endowment of an information object with a code (conditional) designation - a sign or a group of signs (symbols) represented according to a certain system of rules for transmission, storage or storage" [12, p. 34].

Coding is bifurcation in nature. On the one hand, the need to develop and select code. Code is a set of characters and a system of certain rules by which information can be represented (encoded) in the form of a set of certain characters for its transmission, processing and storage. The final sequence of code characters is called a word. Encoding is the procedure for converting a message into a signal.

At the same time, transformations are carried out according to certain rules. A code, as a set of signs, acts as an ideal image of objective reality. Today, communication theory has developed a system of positional and timer codes. These include: simple uniform codes; systematic codes; codes with an even number of units; codes with doubling elements; inverse and others. Of the sign codes, the most common are two- and ten-digit codes.

If the first component of the bifurcation coding character is associated with the choice of code and the coding procedure, then the second is with the creation of technical devices - decoders. Here we can distinguish P.Schilling, inventor of the electromagnetic telegraph (1832), S. Morse inventor of electromechanical apparatus (1837) and developed telegraph code (Morse code), as well as B. Jacobi, D. Hughes, C. Witson, J. Boda, and later others.

Thus, taking into account the philosophical and technical aspects of coding represents it as a sociotechnical process. The social side is associated with the understanding of the quality of the transmitted information as its internal certainty, technical - with the solution of the problems of creating coding and decoding systems, compression of information transmission channels, increasing its transmission speed, the problem of signal attenuation, noise immunity and others.

The above allows us to argue that coding is a strategic technology in the structure of production and transformation of information for communication. 
Symbolization. Among the universal strategic information processing technologies, a special place belongs to symbolization. Symbolization is at the origins of writing in connection with the development of graphic signs (India letters; China - hieroglyphs), and then you can list other regions, because as noted above, they all developed information and recorded it in graphic signs that humanity decodes today.

In philosophy, in connection with symbolization, one can recall the teaching of G. Skovoroda, who in the general picture of the world singled out the macrocosm, microcosm and symbolic world - the Bible, as a set of graphic signs, the content of which is a reflection of the formation and development of the world in a religious aspect.

With close formation, coding and symbolization perform the same function - replacing an object with a sign or symbol represented by a certain system of information transfer rules. In this they are identical. But in essence they are different. A symbol is a form of representing the ideal expression of the content of things and phenomena, relationships, events in the form of a sign or image. Symbols perform various functions in scientific cognition - communicative, epistemological, constructing abstract reality; these are the most important elements of a directly-intuitive approach to cognition. A symbol from the epistemological point of view is a way of knowing the reality surrounding us: being mastered in its essential being in human practice, a symbol makes it possible to explain the essence of one or another cognitive system that it represents.

Every symbol as a product of the activity of our abstract thinking carries a great semantic load, which is determined by the structure and essence of the object being symbolized. In a symbol, meaning does not only indicate the content of the thing itself, but indicates that it logically unites the thing and the symbol. In this aspect, the content of the symbol is multifaceted. A. Losev notes, exploring the nature of the symbol, that "the symbol of a thing is its meaning ..., its generalization ..., its law ..., its regular ordering ..., its internal-external expression ..., its structure ..., its sign, however not dead and motionless, but giving birth to numerous structures ... its sign that has nothing to do with the content of those entities that are designated here $\ldots$ is the identity, interpenetration of the signified thing ... These nine points approximately depict the general meaningful structure of the symbol "[18, p. 272].

A study of the nature of symbols shows that it refers not to their being, which is perceived by the subject, but already reflected in the form of graphs, charts, signs, emblems, and other visual representations. Behind the appearance of the symbol lies their deeper functional nature, closely related to reflection, due to the creative visualization of knowledge.

In our study, we are interested in a symbol as sign transmitting information through modern communication channels, but the symbol and sign are not identical. A symbol is a purposeful, conscious; 
expressed in a sign form specific reflection of an increasing flow of information, contributing to its compaction, compression, increase in the speed of its transmission to a consumer subject.

The property of symbols to express content different from their own nature, to direct thought through them to objects of knowledge, to connect with ideal images, indicates that symbolization is not some kind of passive appendage of the image or a function of external design. In essence, symbolization refers to the creatively productive side of the formation of an object.

Symbolization contributes to the process of transmitting information in its new expression. It appears as a specific function of the process of cognitive reflection, which arises and is formed in the consciousness of the subject in the framework of the transformation of material into ideal images; it acts as a process of translating thoughts about an object into a symbol. Symbolization is carried out with the help of various kinds of tools or symbols, "by which we mean not only external, material phenomena used to express abstract content" [22, p. 149], but also certain products of the reflective activity of the human brain.

Thus, supplementing the strategy of processing and transmitting information, symbolization is not limited only to communication theory, the range of its application is much wider - it is mathematics, computer science, medicine, and a number of other technical sciences, and of course, philosophy and psychology.
Digitalization In the structures of working with information today, digital technologies have become actively included in all areas of society. The catalyst for these processes was economics and finance. But again, recalling Plotinus, it can be argued that the use of digitalization is not a discovery of today. It is related with the symbolization of the transmission of information through digital channels, when instead of a graphic sign - letters, a number is used.

If we go to the sources of digitalization, they can be found even in the emerging mathematical knowledge, in which the method of abstraction was most developed, and then transferred to other natural sciences, later to the technical, and today to the social, for example, today with the development of computer technologies and the introduction of distance learning, a lot of research on education has appeared. So, in Belarus, "heavenly schools" arose on the basis of digital technologies. Today we extend digitalization to a number of socio-economic activities.

However, for the first time the idea of digitalization is discovered in Pythagoras, who hadabsolute number to explain the general picture of the world. He allocated only five numbers for this understanding of her: unit, two, three, four and the "golden" ten. But he laid the foundation for the development of the relationship of numbers - algebraic. An algebraic number is a number that satisfies an equation with integer coefficients.

An algebraic expression is an expression made up of letters and 
numbers (the unity of a symbol and a number!) Connected by signs of algebraic actions: addition, subtraction, multiplication, division, raising to a power, root extraction. Today they are trying to extend the entire schematic of algebraic expression to all spheres of society. Digitalization made us take a fresh look at mathematics, which is confirmed by the announcement in Ukraine of 2020 - the year of mathematics.

Undoubtedly, along with coding and symbolization, today digitalization of information enters into a number of strategic technologies for working with it. "Intentions on the new cognitive quality of subject knowledge (and its social significance - O.P., V. V.) represent it as a set of information about the characteristics of objects of phenomena and processes - this is the result of a person's creative activity aimed at spiritual development of reality in the form of cognition "[4, $\mathrm{p}$. 24]. And digitalization has a clear subject of its research as a system of subject knowledge. In addition, the development of digital technologies contains great intellectual potential, as well as innovation as a trend in working on information [14].

Describing digital technologies, researchers mark them as a new way to solve modern problems. So V. Voronkova claims that "new digital technologies have created new revolutionary ways of combining products and services and the various traditional boundaries between industries are disappearing ... Digital technologies and the infrastructure of global interaction are changing the traditional approach to work and remuneration" [2, p. 32].

At the same time, to use digital technologies "training of specialists is first and foremost necessary, which will help them understand complex production ... namely, knowledge of information and digital technologies and the ability to handle them" $[7, \mathrm{p}$. 128]. A strengthened digital technology tool is able to increase the effectiveness of any activity both for a person and for society - both management, education, and the financial sector, and coordination of their various actions.

Today, the approach to digital technologies in working with information is just unfolding. But the achievements of digital television, computerization and the creation of new computers are a vivid expression of the scientific and social significance of these technologies.

Conclusion. In the study of strategic technologies for working on information, the article explains the essence of civilization as a "quantum" of human history, which has always been involved in the production, processing,

transmission and storage of information.

The essence of information in modern anthropocentric studies is explained and information is explicated as a category of modern scientific knowledge. The content of the processes of integration, simplification and minimization of information is characterized.

But the content of the basic technologies for working with 
information - coding, symbolization and digitalization is disclosed not only from the standpoint of their social significance based on the theory of communication, cybernetics and mathematics, but attention is also paid to their origins, based on the thesis that all civilizations are an information process, they provided the development of information, its implementation, methods of transmission and storage, which allowed it to be left in the extrahereditary memory of mankind.

\section{СПИСОК ВИКОРИСТАНИХ ДЖЕРЕЛ}

1. Водопьянов, П. А., Крисаченко, В. С. 2018. Стратегия бытия человечества. Минск: Беларусская навука. 306.

2. Воронкова, В. Г., 2019. Формування цифрових цінностей цифрового суспільства та суспільства четвертої промислової революції. Матеріали міжнародної науковопрактичної конференції «Освіта як чинник формування креативних компенетностей в умовах цифрового суспільства». Запоріжжя: ЗНУ, 212.

3. Левко, А. И., 2018. Социокультурные предпосылки инновационного развития, монография. Минск: Беларусская навука, 508.

4. Лукашевич, В. К., 2019. Креативное взаимодействие предметного, нормативного и рефлексивного знания: монография. Минск: Беларусская навука, 299.

5. Захарченко, Н. В., Горохов, С. М., Кочетков, А. В. 2018. Информационные параметры позиционных и таймерных кодов. Т. 1. Одесса: ОНАЗ, 212.

6. Захарченко, М. В., 2009. Системи передавання даних. Т. 1. Одеса: Фенікс, 448.

7. Карабельская, И. В., 2007. Использование цифровых технологий в образовательном процессе высшей школы. Вестник УГНТУ. Наука, образование, экономика. Серия экономика, № 1(19), 127-131.

8. Інформаційне суспільство в світі та Україна: проблеми, становлення та закономірності розвитку, 2017: монографія / За ред. проф. Воронкової В.Г. Запоріжжя: ЗДІА, 282.

9. Шваб, К., 2016. Четвертая промышленная революция. М.: ЭКСМО, 138.

10. Starzhinsky, V., 2016. Towarda an Innovation Society / V. Tsepkalo. Minsk: RIVSH, 446.

11. Лазаревич, А. А., 2015. Становление информационного общества, монография. Минск: Беларусская навука, 537.

12. Заренин М. В., 2012. Информация: свойства, ресурсы, инновационные технологии. Гомель: $O A O$ «Полеспечать», 224.

13. Молостов, В. Д., 2005. Старение и гибель цивилизаций. Ростов-на-Дону: Феникс, 416.

14. Пунченко, О. П., 2017. Археология ноосферного образвоания, монография / Н.О. Пунченко. Одесса: Друкарський дім, Друк Південь, 452.

15. Пунченко, О. П., 2013. Цивилизационное измерение истории человечества. Одесса: Астропринт, 448.

16. Пунченко, О. П., 2008-2009. Гносеологическая природа кодирования цифровизации. The Baltic International Academy. The International Transactions in the Humanities. Under the General Supervision of prof. Dr. Phil. Habil. V. Nikiforov, 9, 382.

17. Мосионжник, Л. А., 2006. Антропология цивилизаций. Кишинев: Bbысш. антропол. шк., 468.

18. Лосев, А. Ф., 1991. Философия. Мифология. Культура. М.: ИПЛ. 525.

19. Осборн, Р., 2008. Цивилизация. М.: АСТ: АСТ МОСКВА: ХРАНИТЕЛЬ. 467.

20. Тоффлер, Э., 2004. Третья волна. М.: АCT. 781.

21. Фернандес-Арместро, Ф., 2009. Цивилизации. М.: АCT: АCT MOCКВА. 764.

22. Резников Л. О., 1964. Гносеологические вопросы семиотики. Л.: ЛГУ. 304 .

Basic strategic technology of intellectual duality of humanity in information technology 
23. Хантингтон, С., 2011. Столкновение цивилизаций. М.: АCT. 603c.

24. Шеннон, К., 2004. Некоторые задачи теории информации. В кн.: «Информационное общество». М.: АCT.16-22.

25. Шеннон ,К., 2004. Современные достижения теории связи. В кн.: «Информационное общество». М.: АСТ. 23-40.

26. Винер Н., 1983. Кибернетика или управление и связи в животном и машине. М.: Наука. 45-218.

\section{REFERENCE}

1. Vodopyanov, P., 2018. The strategy of human being / V. Krisachenko. Minsk: Belarus Science. 306.

2. Voronkova, V. , 2019. The Formulation of Digital Values of Digital Suspension and Suspension of the Fourth Industrial Revolution. In the Materials of the International SciencePractical Conference "Scienceas an official formulating creative competencies in minds of digital suspension." Zaporozhye: ZNU. 212.

3. Levko, A., 2018. Sociocultural prerequisites for innovative development monograph. Minsk: Belarus Science. 508.

4. Lukashevich, V., 2019. Creative interactions of subject, normative and reflective knowledge, monograph. Minsk: Belarus Science.299.

5. Zakharchenko, N., 2018. Information parameters of positional and timer codes / S. Gorokhov, A. Kochetkov. Ed. 1. Odessa: ONAZ.212.

6. Zakharchenko, M., 2009. Data Transfer Systems. Ed 1. Odessa: Phoenix. 448.

7. Karabelskaya I. (2007). The use of digital technology in educational process of higher education. Bulletin of USTU. Science, education, economics. Series of Economics, 1 (19), 127-131.

8. Information suspension in Ukraine and Ukraine: problems, development and law of development, 2017: monograph / Ed. prof. V.Voronkova. Zaporozhye: ZDIA, 282.

9. Schwab, K., 2016. The fourth industrial revolution. M.: EKSMO. 138.

10. Starzhinsky, V., Tsepkalo, V., 2016. Toward Innovation Society. Minsk: RIVSH. 446.

11. Lazarevich, A., 2015. The formation of an information society, monograph. Minsk: Belarus Science. 537.

12. Zarenin, M., 2012 . Information: properties, resources, innovative technologies. Gomel: OJSC "Provide". 224.

13. Molostov, V., 2005. Aging and death of civilizations. Rostov: Phoenix.416.

14. Punchenko, O., Punchenko N. 2017. Archeology of no sphere formation, monograph. Odessa: Printing house, Druk Pivden. 452.

15. Punchenko O., 2013. The civilization dimension of the history of mankind. Odessa: Astroprint. 448.

16. Punchenko, O., 2009. Epistemological nature of digitalization coding // Baltic International Academy. International Transactions in Humanities. Under the General Supervision of prof. Dr. Phil. Nikiforov, V. 9, 382.

17. Mosionzhnik, L., 2006. Anthropological civilizations. Chisinau: Higher. Anthropol School.468.

18. Losev, A., 1991. Philosophy. Mythology. Culture M.: IPL. 525.

19. Osborne, R., 2008. Civilization. M.: AST: AST MOSCOW: KEEPER. 467.

20.Toffler, E., 2004. Third wave. M.: AST. 781.

21. Fernandez-Armestro, F. (2009). Civilizations. M.: AST: AST MOSCOW. 764.

22 .Reznikov L., 1964. Epistemological semiotics questions. L.: LS. 304.

23. Huntington S., 2011. Clash of Civilizations. M.: AST. 603.

24. Shannon, K., 2004. Some problems of information theory. From the book: "Information Society". M.: AST. 16-22. 
25. Shannon K., 2004. Modern achievements of communication theory // In the book: "Information Society". M.: AST. 23-40.

26. Wiener, N., 1983. Cybernetics or control and communication in the animal and machine. M.: Science.45-218.

ПУНЧЕНКО, О. П. - доктор філософських наук, професор, професор кафедри стандартизації, оцінки відповідності та освітніх вимірювань, Одеська державна академія технічного регулювання та якості (Одеса, Україна)

E-mail: olegpetr02.09@gmail.com, ORCID iD: https://orcid.org/0000-0003-2694-6841

ПУНЧЕНКО, Н. О. - кандидат технічних наук, доцент, доцент кафедри автоматизованих систем та інформаційно-вимірювальних технологій Odessa State Academy of Technical Regulation and Quality, Odesa Ukraine

E-mail: iioonn24@ rambler.ru, ORCID iD: https://orcid.org/0000-0003-1382-4490

\section{БАЗОВІ СТРАТЕГІЧНІ ТЕХНОЛОГІЇ ІНТЕЛЕКТУАЛЬНОЇ ДІЯЛЬНОСТІ ЛЮДСТВА В ІНФОРМАЦИЙНОМУ ПРОСТОРІ}

Анотація. У статті отримав нове концептуальне 3'ясування зміст цивілізації як інформаційного процесу. Цивілізація з'ясована як глобальний соціокультурний «квант», в основі якого знаходиться специфічна картина ії буття для даної цивілізації і яка чужа для інших. Аналіз цивілізаційних «квантів» історії розкриває духовну синергію минулого людства 3 метою реконструювання його позитиву для сучасності. Цей аналіз являє собою продукт рефлексії нашого мислення понад тими фрактальними об’єктами цивілізації як «квант» - «інваріантами», які добуваються 3 простору іiі світопоглядних установ і подій.

У зв'язку 3 експонціональним зростанням інформаційного виробництва у всіх цивілізаційних «квантах» розкриваються базові стратегічні технології в інформаційному просторі, як результат все зростаючої інтелектуальної діяльності людства з іï оброблення, збереження та захисту. До базових стратегічних технологій можна віднести: кодування, символізація, цифровізація. Кодування розкрито як діалектичний процес взаємозв'язку думки та знаку, перекладу думки у знак; з'ясована гносеологічна природа знаку й знакової ситуації. Проаналізовано цінніснопізнавальний статус символізації.

Символ охарактеризований як форма уяви ідеального виразу речей, явищ та процесів у вигляді образу або знаку. Цифрові технології, як невідмінна ознака ще третьої промислової революції, в умовах розгортання iï нового етапу - четвертої, розвивається в контексті базової стратегії усього інформаційного простору, охоплює усі сфери діяльності сучасних цивілізацій з позицій іiі інноваційного розвитку.

Ключові слова: цивілізація, «Квант», інформація, кодування, знак, символізація, семіотика, цифровізація, технології.

ПУНЧЕНКО, О. П. - доктор философских наук, профессор, професор кафедры стандартизации, оценки соответствия и образовательных измерений, Одесская государственная академия технического регулирования и качества (Одесса, Украина)

E-mail: olegpetr02.09@gmail.com, ORCID iD: https://orcid.org/0000-0003-2694-6841

ПУНЧЕНКО, Н. О. - кандидат технических наук, доцент, доцент кафедры автоматизированных систем и информационно-измерительных технологий, Одесская государственная академия технического регулирования и качества (Одесса, Украина)

Basic strategic technology of intellectual duality of humanity in information technology 


\section{БАЗОВЫЕ СТРАТЕГИЧЕСКИЕ ТЕХНОЛОГИИ ИНТЕЛЛЕКТУАЛЬНОЙ ДЕЯТЕЛЬНОСТИ ЧЕЛОВЕЧЕСТВА В ИНФОРМАЦИОННОМ ПРОСТРАНСТВЕ}

\section{Аннотация}

В статье получило новое концептуальное объяснение содержание цивилизации как информационного процесса. Цивилизация раскрыта как глобальный социокультурный «квант», в основе которого лежит специфическая картина ее бытия для данной цивилизации и чуждая для других. Анализ цивилизационных «квантов» истории раскрывает духовную синергию прошлого человечества с целью реконструирования всего его позитива для современности. Этот анализ представляет собой продукт рефлексии нашего мышления над теми фрактальными объектами цивилизации как «кванта» - «инвариантами», которые извлекаются из пространства ее мировоззренческих установок и событий.

В связи с экспонциональным ростом информационного производства во всех цивилизационных «квантах» раскрываются базисные стратегические технологии в информационном пространстве, как результат все возрастающей интеллектуальной деятельности человечества по ее обработке, хранению и защите. К базовым стратегическим технологиям отнесены: кодирование, символизация и цифровизация. Кодирование раскрыто как диалектический процесс взаимосвязи мысли и знака, перевода мысли в знак; объяснена гносеологическая природа знака и знаковой ситуации. Проанализирован ценностно-познавательный статус символизации.

Символ охарактеризован как форма представления идеального выражения вещей, явлений и процессов в виде образа или знака. Цифровые технологии, как неотъемлемый признак еще третьей промышленной революции, в условиях развертывания ее нового этапа - четвертой, развиваются в контексте базовой стратегии всего информационного пространства, охватывая все сферы деятельности цивилизаций с позиций ее инновационного развития.

Ключевые слова: цивилизация, «квант», информация, кодирование, знак, символизация, семиотика, цифровизация, технологии. 